\title{
Asylum Seekers and Refugees in Indonesia:
}

\section{Problems and Potentials}

\author{
Muzafar Ali \\ Independent Researcher \\ Linda Briskman \\ Swinburne Institute for Social Research \\ Lucy Fiske \\ University of Technology Sydney
}

\begin{abstract}
Asylum seekers and refugees in Indonesia increasingly experience protracted waiting times for permanent settlement in other countries. They have few, if any, legal rights, coupled with extremely limited financial resources and no access to government provided services. In response to the prospect of living for many years in this difficult and liminal space, a small community of refugees in the West Java town of Cisarua has built relationships, skills and confidence among themselves and with host Indonesians to respond to identified needs. This paper outlines the main political and policy frameworks affecting the lives of refugees in Indonesia and then draws on research interviews and participant observation to illustrate the resilience and agency utilised by the community to mitigate uncertain futures. The major focus is on education for asylum seeker/refugee children.
\end{abstract}

\section{Introduction}

Increasingly protracted situations confront forced migrants in Indonesia. This cohort includes asylum seekers (awaiting determination of their refugee status) and those who have been granted asylum (refugees) who are awaiting third country resettlement ${ }^{1}$. The time of waiting can extend for several years and is marked by marginality - of attaining a level of immediate safety, but with no realisable rights beyond an assurance of non-deportation. Asylum seekers

\footnotetext{
${ }^{1}$ At times the terms asylum seeker and refugee are used interchangeably in this paper, to reflect the literature and common usage.

Linda Briskman, Faculty of Health, Arts \& Design, School of Arts, Social Sciences and Humanities, Swinburne Institute for Social Research, Swinburne University of Technology. Lucy Fiske, Faculty of Arts and Social Sciences, University of Technology Sydney. Corresponding author: lbriskman@swin.edu.au ISSN: 1837-5391; https://epress.lib.uts.edu.au/journals/index.php/mcs CCS Journal is published under the auspices of UTSePress, Sydney, Australia (C) 2016 Muzafar Ali, Linda Briskman, Lucy Fiske This is an Open Access article distributed under the terms of the Creative Commons Attribution 4.0 Unported (CC BY 4.0) License (https://creativecommons.org/licenses/by/4.0/), allowing third parties to copy and redistribute the material in any medium or format and to remix, transform, and build upon the material for any purpose, even commercially, provided the original work is properly cited and states its license.
} 
and refugees in Indonesia face a broad range and intersecting web of problems and obstacles; this forms the 'problems' section of the paper. Yet, despite (or perhaps because of) these obstacles, asylum seekers and refugees in Indonesia are exercising creativity, resilience and resourcefulness to create community spaces through which they are able to meet basic needs and build lives which provide purpose and fulfillment beyond mere survival. This paper focuses in particular on the educational needs and rights of refugee and asylum seeker children in Cisarua, a West Java township 70 kilometres from Jakarta, and the ways in which the community has organised to ensure their children's education is not disrupted during the protracted wait for refugee resettlement. We first present an outline of Indonesian policies towards refugees and the effects of these policies on the daily lives of refugees living there. We then outline some recent changes in Australian refugee policies and the impact of these policies on the situation for refugees in Indonesia, before shifting to look more closely at the Afghan and Pakistani Hazara community in Cisarua (West Java), including the reasons for their displacement and, more particularly, the initiatives they have developed to partially overcome their social, legal and political exclusion.

\section{Methodology}

This paper uses a mixed methodology, drawing on participant observation of Muzafar Ali's lived experience and qualitative research undertaken by co-authors Linda Briskman and Lucy Fiske. Ali is a Hazara man, originally from Afghanistan and now a permanent resident in Australia. Briskman and Fiske are academics with extensive experience in conducting research with asylum seekers and refugees. Ali was a participant in the research described below, conducted by Briskman and Fiske. They subsequently met again at the symposium forming the basis of this special issue of Cosmopolitan Civil Societies Journal, in September 2015, at which time they decided to jointly write this paper, drawing together both academic and experiential material to build a richer exploration of life for refugees in Indonesia than either account could achieve separately.

In recent years there has been a burgeoning of academic interest in asylum seekers and refugees in transit in Indonesia. Nethery et al. (2015) explore immigration detention in that country. Briskman and Fiske (2016) discuss how Australia’s policies have the effect of criminalising asylum seekers and refugees in Indonesia. Sampson et al. (2016) discuss interviews that reveal how agency is exercised in situations of protracted precariousness. In empirical research in three Indonesian provinces, Missbach (2015) includes accounts of daily 
hardships for those in a situation of limbo. Our research takes an innovative methodological direction. It combines an auto-ethnographic approach (Ellis et al. 2004) whereby the lived experiences of Muzafar Ali inform the wider political and social context, with interviews conducted by the other authors.

Before seeking asylum, Ali's most recent employment was with the United Nations Assistance Mission in Afghanistan (UNAMA) and the United Nations Development Program (UNDP), working in a disarmament program monitoring political, security and human rights issues; through which he developed research skills. Largely due to this work, in 2012 he became a refugee, fleeing with his family via Pakistan and Malaysia to Indonesia. He spent one year and eleven months living in Indonesia with his wife, young daughter, mother, sister and three other relatives until they were resettled to Australia in 2015. During his time in Indonesia, Ali directly experienced the difficulties outlined in this paper. He was a cofounder of the Cisarua Refugee Learning Centre (discussed later in the paper). He was active in the community in Cisarua, forming friendships with fellow refugees, Indonesians and international visitors, attending community meetings, and participating in key community development activities. Ali kept records of his experiences both in Afghanistan and during his refugee journey, including his time in Indonesia. Ali's records, created contemporaneously, include films, photographs, minutes of community meetings, emails and a personal journal. These records are drawn on as a source in this paper.

In keeping with our combined methodology, the paper recounts Ali's lived experiences and documentation of his and other refugees' lives in Indonesia and draws on a research project conducted by Briskman and Fiske titled Informal Protection Space in Indonesia. This was a small qualitative research project with fieldwork conducted in December 2013 through semistructured interviews with 30 refugees and asylum seekers living in Cisarua, and with representatives from organisations working with refugees and asylum seekers in Indonesia, including UNHCR, International Organization for Migration (IOM) and legal services. Refugee research participants included 13 women and 17 men, and represented refugees separated from their families by refugee flight, as well as those living in family groups both with and without children. All participants were adults and came from Afghanistan, Pakistan, Iran and Sri Lanka. Both individual interviews and focus group discussions were conducted. Interviews were semi-structured with questions designed to elicit information under the broad thematic areas of safety, health, education, livelihood, housing, family and cultural life, 
information sources and decision-making processes. All interviews and focus group discussions were transcribed and thematically analysed.

\section{Indonesia: asylum seeker policies and effects}

Indonesia is the world's fourth most populated country, spread over more than 14,000 islands. Indonesia is predominantly Sunni Muslim, but it is also religiously, ethnically and linguistically diverse, with over 700 different languages and dialects spoken, over 300 different ethnic groups and significant populations of Christians, Hindus and Buddhists (CIA 2015; USCIRF 2013, 1). Although Indonesia is South East Asia’s biggest economy and a member of the G20 group of countries, half of its population is living in poverty with limited job opportunities (Handayani 2012). Health and higher education is mostly unaffordable for ordinary Indonesians. While Indonesia is developing rapidly, its public infrastructure, including schools, clinics, hospitals and roads, is greatly overshadowed by the public need (OECD 2015).

Indonesia is not a signatory to the 1951 Convention Relating to the Status of Refugees (known as the Refugees Convention); nor is there domestic law in place to protect refugees. Indonesia is a transit country (rather than a destination country), where many asylum seekers and refugees previously intended to stay for only a short time before travelling onwards to Australia. As a non-signatory to the Convention, Indonesia does not conduct refugee assessments, nor offer any pathways for refugees to attain permanent residency there. Nonetheless, Indonesia hosts more than 13,000 refugees and asylum seekers; mostly from Afghanistan and Pakistan, but also from Myanmar, Iraq, Iran, Sri Lanka and other countries (UNHCR 2016, p. 1). Refugees and asylum seekers arrive in Indonesia either by plane (for those with travel documents and access to a visa) or by boat, most commonly via Malaysia. Asylum seekers pay between USD5,000 - 10,000 to people smugglers who facilitate their risky journey to Indonesia. Typically a refugee will fly to Kuala Lumpur, and then travel on fishing boats to North Sumatra in Indonesia by crossing the Strait of Malacca. The smugglers pay bribes to Malaysian and Indonesian authorities to give their passengers a safe passage through airports and other checkpoints.

On their way to Indonesia, asylum seekers are soft targets for local smugglers and authorities. All three authors met refugees who reported that Malaysian authorities took away all their 
belongings including their cash, mobile phones and watches and they searched the women for jewellery. Other refugees reported that local smugglers had stopped their journey and demanded more money from the refugees.

Once refugees have arrived in Indonesia, most travel to the capital, Jakarta, where they register with the United Nations High Commissioner for Refugees (UNHCR). Refugees are issued documentation by the UNHCR which identifies them as asylum seekers ${ }^{2}$, which offers them protection against possible deportation. Registration also begins the Refugee Status Determination (RSD) process. The UNHCR invites them to an RSD interview and determines whether they will be granted refugee status according to the 1951 Refugees Convention. In August 2015 the waiting period for an RSD interview was up to twenty months, with a decision on the outcome coming some time after that. For people recognised as refugees in Indonesia, resettlement is the only available durable solution as return is impossible and Indonesia does not permit local integration. Precise time frames for this process are difficult to establish due to changing politics of refugee displacement and resettlement. Resettlement seldom takes less than two years and may take very much longer. Briskman and Fiske interviewed several Sri Lankan refugees who had been advised by the UNHCR to expect resettlement in six years ${ }^{3}$.

In November 2014, then Minister for Immigration Scott Morrison announced that any refugees registering with the UNHCR in Indonesia after 30 June 2014 would be ineligible for resettlement to Australia (ABC 2014b). The changes in Australia's asylum seeker and refugee policies, alongside the diversion of UNHCR funds to respond to the Syrian refugee crisis, have caused significant extensions to the processing and resettlement times for refugees applying from Indonesia (UNHCR 2015b, 52). Thus a newly arrived refugee can now hope to be resettled in a third country five years or more after arriving in Indonesia.

Living arrangements for asylum seekers and refugees during this time of waiting vary, including in immigration detention centres and community centres in Jakarta and on other Indonesian islands. There is a large community of between 3,000 and 5,000 refugees and asylum seekers living in Cisarua. They rent accommodation from local Indonesians and

\footnotetext{
${ }^{2}$ An asylum seeker is a person who has applied for recognition as a refugee, but who is awaiting a decision on that application.

${ }^{3}$ Interviewed December 2013.
} 
frequently experience overcrowding to defray rental and associated costs. Apart from a minority receiving a small allowance from the NGO, Jesuit Refugee Service, most of those living in Cisarua rely on remittances from their families and friends abroad, which results in a struggle for the basics of life such as food and health care. Yaqub ${ }^{4}$ told us in an interview that his friend in Afghanistan sends him money when he can and a contact in Australia also provides some help. Others told us similar stories but shadowing this was a sense of shame and guilt as they had hoped to be able to support their families back home and not to be recipients of charity or a burden on families whom they know to be impoverished. A group of Sri Lankan asylum seekers, including families with children, reported that it is only through extensive sharing of food, money and accommodation, and additional food support from a nearby Hindu temple that they are able to meet their basic needs. ${ }^{5}$ The implications of extended waiting periods are explored in further detail in a later section of this paper.

\section{UNHCR}

The UNHCR is under-staffed and its budget is insufficient to adequately deal with refugee issues in Indonesia (UNHCR 2015b). Our conversations with asylum seekers suggest that UNHCR case officers are often young Indonesians, often lacking sufficient knowledge about the asylum seekers' country situation or of complex protection needs of some refugees ${ }^{6}$. As a consequence, people in need of protection may in fact be refused by the UNHCR due more to inadequacies in the system, such as inexperienced case officers, but also including a lack of legal assistance for asylum seekers, advice (sometimes incorrect) circulating within asylum seeker communities and inadequate systems for identifying individual vulnerabilities such as mental health problems or cognitive impairments.

The situation is not static. Refugees continue to arrive in Indonesia. At February 2016, there were 13,829, the vast majority from Afghanistan (UNHCR 2016), reflecting ongoing instability in that country. Australia's closure of resettlement opportunities for refugees in Indonesia has made the UNHCR's task of resettling refugees more difficult as it must now convince other resettlement countries further afield (such as the USA, Canada and Sweden) to resettle refugees through its Indonesian operations. On a global scale, UNHCR's projected

\footnotetext{
${ }^{4}$ All names have been changed to a pseudonym. Interviewed December 2013.

${ }^{5}$ Interviewed December 2013.

${ }^{6}$ Lucy Fiske has on file a December 2015 job advertisement for a 'Protection Associate’ position responsible for Refugee Status Determination decisions which requires a 'minimum completion of secondary education but preferably a university degree in law, political science or related disciplines.'
} 
resettlement needs for refugees in 2016 is 1,150,000, an increase of $66 \%$ from the estimated needs for 2014, with much of this increase attributed to the Syrian conflict. The 80,000 resettlement places made available by member nations in 2015-16 will fail to meet this need (Gifford 2015). Higher numbers of arrivals and the limited number of departures from Indonesia result in a refugee crisis, in terms of limited capacity for processing, support and resettlement. The Indonesian government, UNHCR and IOM have limited resources for refugees and, as we explain later, the wealthy neighbouring country of Australia lacks political will.

\section{Australia: asylum seeker policies and effects}

Unlike Indonesia, Australia is a signatory to the Refugees Convention and therefore has international legal obligations toward refugees and asylum seekers who arrive on Australian shores. Australia has implemented a raft of policies aimed at preventing asylum seekers from arriving in Australian territory. As a staging post for asylum seekers en route to Australia, the consequences for Indonesia and those seeking asylum within that country is a steady increase of people in protracted situations. Stopping boats has underpinned Australian asylum seeker policy since 1992 when mandatory immigration detention was introduced by a Labor government with bipartisan support. It is beyond the scope of this paper to document full details of the stringent policy domain but information is readily available ${ }^{7}$.

The overall policy thrust is encapsulated in the 2013 words of then Immigration Minister Scott Morrison: 'Let me be clear. I’m trying to stop people illegally entering Australia by boat. That's our objective' (cited in ABC 2013), and backed up by messaging devices to target would-be arrivals, including a poster showing a small boat in the ocean, specifying: ‘No Way by boat: You will not make Australia home’ (Fleay et al. 2016, 3).

In September 2013 former Australian Prime Minister Tony Abbott launched Operation Sovereign Borders (OSB) and it continues today (in 2016). OSB has had significant negative impacts on refugees' lives in Indonesia. OSB is defined by the Department of Immigration and Border Protection (DIBP) (nd) as 'a military led operation supported and assisted by a wide range of federal government agencies.' Through this policy, boats are intercepted and turned back to source and transit countries such as Indonesia; the capacity of offshore

\footnotetext{
${ }^{7}$ See for example http://www.refugeecouncil.org.au/fact-sheets/, http://www.asrc.org.au/resources/factsheet/\#1375939566-2-31
} 
detention in Nauru and Papua New Guinea (Manus Island) has extended; and, although no longer operational, purchasing and deploying specially designed orange lifeboats to turn back asylum seekers who were transiting in unseaworthy boats. Not only have the turn-backs had a devastating impact on returned asylum seekers, but Australia’s relationship with Indonesia has been put at risk through breaches of Indonesia's maritime borders by the Australian Navy (ACBPS and ADF 2014, para 10).

Muzafar Ali explains the direct impact of OSB on asylum seekers in Indonesia based on his personal experiences of living and working with the refugee community in Cisarua:

Prior to OSB, refugees and asylum seekers would rush to find a people smuggler to take them to Australia as soon as possible. They still registered with the UNHCR and got identification papers but only to avoid arrest by police and having to pay bribes. Because once the asylum seekers register to UNHCR, they get an ID card and asylum seekers can stay in Indonesia as long as their RSD and resettlement process is ongoing. The authorities usually do not arrest asylum seekers with UNHCR cards.

Refugees would move frequently in order to avoid arrest, and because of the regular departure of roommates, their life was full of chaos, fear and restlessness. The smugglers had a grassroots network within refugee communities and exploited the situation in order to find more clients to fill Australia-bound boats. Constant rumours of new boats leaving reverberated through the community, and smuggling agents would gather payments and arrange transportation to the south coast of Java where most boats left for Christmas Island. Often these boats failed even before leaving Indonesian waters. One of the most important effects of the constantly changing and chaotic environment, and the rumours and misinformation purveyed by smugglers' agents, was that refugees were fearful and didn’t trust anyone. The lack of trust within the community made forming any kind of self-help or positive development impossible.

OSB mostly stopped boats leaving, but it did not stop refugees arriving in Indonesia. Rather, refugee arrivals of Hazara increased due to the increasing instability in Afghanistan. Taliban activity had increased and the targeted killings of Hazara continued when two blasts within 40 days killed at least 250 people in Quetta City. More recently, hundreds of Myanmar’s Rohingya Muslims, Iraqi and Syrian refugees 
have come to Indonesia. The community was growing as the arrivals continued but departures all but stopped. People had increased financial difficulties as they have to wait for many years to get resettled. Many refugees who could not find support from anywhere, turned themselves in to Indonesian authorities, asking to be put in detention to get food and shelter. Within a year, detention and community centres were filled beyond capacity and hundreds of refugees camped outside immigration centres waiting to be accepted.

Some refugees voluntary deported themselves to Afghanistan. In one particular case, a prominent young Hazara singer, Aref Shadab, returned to Afghanistan and was subsequently kidnapped by the Taliban on his way to his home while travelling on the Kabul-Kandahar highway ${ }^{8}$. He was kidnapped along with his friend Dilshad (also a singer), the driver and two passengers, all Hazara. Aref was released after paying a substantial ransom ${ }^{9}$.

Among those refugees who remained living in the community in Cisarua, some leaders began to emerge, determined to rebuild trust among the community and to develop ways of supporting one another. Some refugees with more education and with language and other specialist skills started to arrange volunteer interpreting and counselling services.

Relationships began to build within the community as the refugees came together to discuss and solve problems. This community building was a big change from how refugees lived in Indonesia previously and true refugee communities started to establish. Education was the perfect issue to bring refugees closer and to develop practical solutions to their problems. It was one of the most important issues for refugee parents. Many educated refugees in the

\footnotetext{
${ }^{8}$ A number of Hazara News sources have reported his abduction as occurring on 16 June 2015, including Hazaras in Indonesia, Mulla Sarpalas, and Humayoun Behzad and Khama Press http://www.khaama.com/gunmen-kidnap-two-singers-in-ghazni-3491

${ }^{9}$ Aref Shadab recalls his account in a telephone interview with an Afghan radio station "Radio Payam Javan Jaghori" published on its facebook page https://web.facebook.com/radiopayamjavan/videos/1065350080172831/ (in Hazaragi) and in a video interview with Geo Hazara Channel https://web.facebook.com/253796511472069/videos/494479644070420/ (in Hazaragi). His friend Dilshad and another passenger were killed by the Taliban a few hours after they were kidnapped. The Taliban accused Aref of singing and of having five brothers in Australia. They threatened to kill him unless he paid the ransom. He was eventually released in Zhob, a town in the Balochistan province of Pakistan. News of targeted kidnapping in Afghanistan is plentiful, with Hazaras among a number of identified targeted groups. See for example, Goldstein, J and Shah, T., 2015, ‘Afghan Kidnappers Prey on Hazaras', The New York Times (15 November). Accessed 17 April 2016, http://www.nytimes.com/2015/11/22/world/asia/kidnappings-escalate-in-afghanistan.html?_r=0
} 
community were willing to serve through their skills and they discovered that that this was an issue they were able to solve themselves.

The community building and self-help actions of the Hazara community in Cisarua is explored in detail after a brief explanation of the causes of displacement for Hazara people from Afghanistan and Pakistan, and an overview of life for refugees in Indonesia (Hazara and other nationality and ethnic groups).

\section{Ethnic Hazaras}

A large percentage of refugees in Indonesia are ethnically Hazara; Shi'ite Muslims originating from Sunni dominant Afghanistan and Pakistan. They are physically distinct from other ethnic groups in both Afghanistan and Pakistan, and are therefore readily identifiable. Historically, Hazaras have been subject to systematic persecution in Afghanistan. There have been more recent slayings, including when the Taliban carried out brutal mass killings of Hazaras in 1990s when they captured the areas of Bamyan, Yakawlang and Mazar-e-Sharif. One of the most brutal attacks against Hazaras occurred on 8 August 1998 when the Taliban massacred over 2,000 Hazara men, women and children in Mazar-e-Sharif (HRW 1998).

After experiencing brutality during the Taliban regime, Hazara people supported international community efforts to install a democratic and more progressive government in Afghanistan. Many are now paying the price of supporting the international community. As the Taliban strengthens its grip, in conjunction with the withdrawal of international forces, the Taliban has conducted what many Hazaras believe are revenge attacks including the kidnapping and murder of Hazaras. Many Hazaras fled Afghanistan to Quetta City in Pakistan from the late 1990s onwards. There they are increasingly the subjects of targeted killings based on their ethnicity and religion by the extremist religious groups, Lashkar-e-Jhangvi and Jaish-ul-Islam, linked with Taliban and Al-Qaeda. In 2011 Lashgar-e-Jhangvi issued a statement declaring their intention to rid Pakistan of Hazaras saying, 'As in the past, our successful jihad against the Hazara in Pakistan and, in particular, in Quetta is ongoing and will continue in the future. We will make Pakistan the graveyard of the Shia Hazara' (cited in Ahmed 2014). Some Hazaras, particularly those with an education, worked for US and Australian forces, or with local and international aid agencies engaged in security, aid and development interventions in Afghanistan. While many were motivated by a desire for transformation in Afghan politics 
and society, the lack of 'success' in Afghanistan and the resurgence of the Taliban has arguably increased the risks of persecution against the Hazara people. Consequently, it is likely that Hazaras and other Afghans are likely to continue to seek asylum in Refugees Convention signatory countries over the coming years.

\section{Asylum seeker life in Indonesia}

Indonesian policy towards refugees and asylum seekers is best described as one of tolerance. While Indonesia has thirteen long term and twenty short term immigration detention centres, refugees are generally permitted to reside in the community while their cases are processed by the UNHCR (Global Detention Project 2015). In August 2015 there were 4,273 people of concern to the UNHCR held in Indonesian detention centres (UNHCR 2016, 2). While undergoing UNHCR processes, refugees are not entitled to social security, to work or start their own businesses. This is understandable, given that half of Indonesia's population is living at or below the global poverty line. Engagement by refugees in income generating pursuits may be seen as competing with Indonesian livelihoods. Refugees in Indonesia must find ways to sustain themselves.

Refugees face many challenges when they arrive in Indonesia. The major difficulties raised by refugees (regardless of their nationality or ethnicity) during interviews conducted in December 2013 included: livelihood and financial difficulty, health, safety and security, lack of legal rights, mental health problems, boredom and education for their children.

Financial problems create significant hardship. According to Ali the monthly cost of accommodation, food and transport for one refugee in Jakarta or Cisarua is approximately USD130. Health, clothing, education and other basic needs add to the costs. Refugees rely on savings, sell whatever valuable items they may have brought with them (such as jewellery or watches) or are supported by relatives overseas. With an average wait for resettlement of approximately five years, this becomes a massive burden on their savings and their relatives, who are very often living in economically marginal and precarious situations themselves. 'Savings, exchangeable articles of value and remittances usually did not last very long and, sooner or later, support from friends and kin ran out’ (Missbach 2015, 101). 
The cost of living for many years without income in Indonesia has led some refugees to selfsurrender to immigration detention centres, despite knowing about the poor living conditions. In detention, refugees are typically kept in locked cells and sometimes subject to mistreatment by the authorities (Missbach and Sinanu 2013). Health and sanitation conditions are extremely poor and doctors are slow to respond to refugee health issues (HRW 2013). With detention centres and IOM community housing spread across different islands, staff from the UNHCR visit on a slow rotation, delaying the resettlement process. Waiting time for refugees in detention is often longer than for those in Jakarta and Cisarua. Many refugees in Indonesian detention centres are distressed. Deprived of freedom of movement, locked up for long hours, away from their families, poor living conditions, lack of recreation and long and unclear resettlement times add to this stress. In these circumstances, 20 year old Ali Mohammad, a Hazara refugee, committed suicide in a detention centre in Surabaya on 10 February 2015 (Hazara Asylum Seekers 2015; Beyond Foreignness n.d.).

Ali points out that health facilities in Indonesia are often too expensive for refugees struggling to meet the costs of food and rent, resulting in reluctance to seek treatment. Many children are undernourished and there are many refugees and asylum seekers suffering from depression who require psychological and mental health support. In some cases, unaccompanied young refugees are infected with sexually transmitted diseases due to a lack of knowledge about HIV/AIDS. In fieldwork interviews conducted in December 2013, we found that asylum seekers and refugees adopted creative ways to ensure that there was at least minimal access to health care. Asylum seekers and refugees with a health qualification were willing to diagnose and make suggestions for treatment in cases that did not require hospitalisation. More concerning was the interview participant who told us that although he was untrained, he had previously held an administrative position in a hospital in Pakistan and was sometimes called on to diagnose and recommend pharmacy-available medications to fellow community members. He explained that 'sometimes I go to the apotek ${ }^{10}$ looking for the formula... Sometimes it works, sometimes it doesn't. ${ }^{11}$ He further explained that he uses the internet, including auto-translation programs, to identify possible medications and their names in Bahasa Indonesian.

\footnotetext{
${ }^{10}$ Term for pharmacy

${ }^{11}$ Interviewed December 2013.
} 
Refugees and asylum seekers are from different cultural groups from host communities. Living and adjusting to a community with a different language, social norms, cultural practices and religious rituals is an added challenge for the refugees. A majority of the Indonesians are Sunni Muslim while many refugees are Shi'ite, a different denomination of Islam. While the majority of Indonesians are accepting of people of other faiths, there has been a significant rise in fundamentalist Sunni Islam (known as Wahabism) in recent years (von der Mehden 2014; Bachtiar 2013). Consequently, many refugees cannot practice their religion freely. Their fear is not unfounded. A series of attacks on Shi'ite communities in Indonesia led the United Nations High Commissioner for Human Rights, Navi Pillai, to approach the Indonesian government in November 2012, urging it to take action to protect religious minorities in the country including through repealing blasphemy laws and through more pro-active protective measures (Agence France 2012). As recently as December 2015, Indonesian police arrested a 'terror cell' planning attacks against Shi'ite Muslims and Christians (Al Jazeera 2015).

Nonetheless, asylum seekers and refugees in Cisarua enjoy relative freedom of movement and report generally good relationships with their Indonesian neighbours. Despite not being permitted to work in Indonesia and notwithstanding language communication problems, relationships with local Indonesians are mostly harmonious and respectful. While some refugees told us of arguments or violent incidents with Indonesians, most of the people we interviewed in Cisarua in 2013 said that relationships with Indonesians were positive. Nonetheless they considered they had to keep a low profile, to be 'under the radar' and try to meld into the population as discreetly as possible (Agier 2008, p. 20). Issaq explained the situation well, saying:

We feel safe if we go to the bazaar. We don't think that 'this person will kill me, this one kill me, this one kill me.' No. In Quetta, when I go to the Bazaar, most of the time I am afraid, scared. In here I don't have this problem. ... But here we could not perform any activity like Muharram (an important Shi-ite celebration). We are just sitting in our home, sitting in one site, quiet, because it could be a problem if we celebrate our Muharram ${ }^{12}$.

Refugees and asylum seekers in Cisarua live in a liminal zone of tolerance and exclusion. As Mohammad explained:

\footnotetext{
${ }^{12}$ Interviewed December 2013
} 
Indonesia...temporarily provides us safe haven. We are living here, but we're not. We feel more secure than we did in our country, but we are still very vulnerable. We can be stopped by the police and they can get a bribe to release us. We can be looted. We can be treated like animals. [We cannot] report to the police because we think that if we report to police, the police will prefer the statement of the local people ${ }^{13}$.

As asylum seekers are not permitted to work or conduct any income generating business, interview participants spoke about being forced into dependency on relatives overseas, community members or charities. Some asylum seekers earned very small sums of money through producing goods for sale within asylum seeker and refugee communities, such as by making Afghan bread. The overwhelming consensus among the thirty people interviewed, and through Ali's participant observations, is that refugees and asylum seekers generally feel safe from physical attack, but are acutely aware of their non-belonging and try to 'stay quiet' and invisible.

A large number of refugees are families with children. Education remains one of the biggest concerns for their parents. Children recognised by the UNHCR as refugees are permitted to attend local Indonesian schools, but those still considered asylum seekers do not have this entitlement. In parts of Indonesia, some school principals permit asylum seeker children to enrol; nonetheless the majority are left without access to formal education (Missbach 2015). Classes are delivered in Bahasa Indonesian and children must learn Bahasa before enrolling. There are no subsidised Bahasa courses available and private lessons are beyond the means of all families that we met. Language is thus a key barrier.

For children, exclusion from education for many years is a major loss and will likely compound social and economic disadvantage for years to come, restricting their ability to fulfil their potential in later life. As noted by the UNHCR (2012) 'Refugees value education and place it high on their priorities. Quality education that builds relevant skills and knowledge enables refugees to live healthy, productive lives and builds skills of selfreliance.' Indeed, all of the parents interviewed expressed great concern about disruption to their children's education. In addition to skills and knowledge development, education has significant emotional and mental health benefits, providing the children with structure,

\footnotetext{
${ }^{13}$ Interviewed December 2013.
} 
purpose and goals to work towards. Education is a challenge the refugees in Cisarua have stepped up to provide.

\section{Education in Cisarua}

When Briskman and Fiske conducted interviews in Cisarua in 2013, the consequences of children missing out on schooling was causing great distress to parents. Although an Indonesian NGO had suggested that children learn Bahasa and seek entry to local schools, there was general reluctance. Asylum seekers and refugees saw Cisarua as a temporary transit site and engaging in the formal education system would arguably signal that they might be putting down roots. This was despite the knowledge that their situation was likely to be protracted. For example, one family told us that the UNHCR had warned them to expect a six-year waiting period. They desperately wished for their children to be educated in English as they believed that English language skills and education would better prepare them for a good future, whatever that might be. Despite the long period of waiting, they resisted nonEnglish alternatives ${ }^{14}$. To compensate for such scenarios, educated asylum seekers and refugees with high levels of English gave their time and skills to set up informal classes for children but this only went part-way to resolving the education situation. It was after we left that a new initiative, the Cisarua Refugee Learning Centre (CRLC) emerged and, as one of the founders, Muzafar Ali describes its background and operation:

The CRLC is a school established and managed by the refugees to provide education for their children. The school is informal and not registered with the government and its establishment was important in boosting the community's confidence. They did not rely or wait for any organisation to start assisting them. They came together and acted on their own initiative and discovered that they could act collectively and independently to support their needs.

The CRLC changed the misconception that refugees cannot engage in any kind of social activities, and that refugees are not allowed to teach and learn. It also provided a space where the community could meet and share their concerns. It has become a very important social and cultural space for the community. Later on these communities started to organise social events, including birthdays, funerals and religious gatherings.

\footnotetext{
${ }^{14}$ Interviewed December 2013.
} 
Once the community started the school, they decided to teach in English because most of the countries of resettlement are English speaking.

\section{Establishing the CRLC}

There are more than 500 children living with their families in Cisarua and no school for refugees. Existing Indonesian schools teach in Bahasa, Indonesian language, making it nearly impossible for the refugee children to attend. Without school the children spent their days on the streets doing nothing, and not sleeping until late at night. With nothing to occupy them they became very affected by the depressed situations in their homes.

In October 2013 some young refugees started to organise regular and formal meetings to discuss the community's challenges. They held meetings in different areas of Cisarua to encourage other refugees to join and share their own experiences. It took almost a year to build up trust and understanding. In this time they established networks, identified problems and discovered the refugees' capabilities and limitations. Eventually, due to rumours, misinformation, and fear of jeopardising their asylum application with UNHCR, most of the refugees left the group.

Those remaining decided to start a school for refugees in Cisarua in August 2014. They rented a small house with two rooms and a corridor. They started this school with three classes and seven teachers, all of them women because male teachers feared jeopardising their asylum claims. Thus, women showed more courage to teach the children than the men who held private classes for other male refugees. Within one week the school had more than 50 students. Some parents even moved from Jakarta to enrol their children. The parents contributed 50,000 Indonesian Rupiah (equivalent of AUD5.00) per student to buy carpet, a white board, markers and a few notebooks. After this initial contribution, the parents paid 15,000 Rupiah (AUD1.50) per month per student. This amount was enough to buy potable water, gas and to pay electricity accounts. Parents would clean the school and help the school run on a daily basis according to a roster.

The school runs classes from 9.00am to $1.00 \mathrm{pm}$, Monday to Thursday. All the teachers are volunteers and do not receive any salary. The parents organise weekly meetings and this is an opportunity for them to share information and to discuss social issues. Soon 
the school became a trusted place to discuss serious issues. Those parents, who did not know each other before the school, became close friends. The children loved to come to school because they enjoyed learning and playing with other refugee children.

The CRLC was more than a school for the community. It provided them with activity, a sense of pride, enjoyment, togetherness and comfort. It would not be a stretch to say it gave them their very identities back. They moved from faceless refugees hiding in the shadows, to being teachers, students, managers, sports co-ordinators, carpenters, bookkeepers and parents who were providing for their childrens' futures.

The children formed soccer teams and soon the women, mostly teachers, made two teams of their own. For many of these women it was their first time playing soccer. In Pakistan and Afghanistan women playing soccer is unusual; this was a very new experience for everyone. It was like a revolution for a fearful, depressed and newly established community to open up and express their existence with education and sport.

The students at CRLC are mostly Hazaras from Afghanistan and Pakistan. But other students are from Iraq, Iran, Myanmar and Sudan. The management decided to teach an Australian curriculum in the English language. Teaching in English was a great challenge because the children are from different countries and backgrounds, but the CRLC has played a big part in bringing parents from different countries closer to each other.

There are now another three learning centres for refugee children in Cisarua and Jakarta, replicating the CRLC model, and nearly 300 children benefit from education on a regular basis. When CRLC started on August 2014, it was very hard to find teachers to volunteer, but now there are more than 30 teachers across all the learning centres.

The initial group of refugees who established the CRLC were inspired and motivated by an Australian couple based in Jakarta and an Indonesian woman working for a refugee organisation. An Australian couple pledged to pay the rent for the school building and provided more stationery and materials needed for the school. They also facilitated a good friendship between the CRLC and the Australian Independent School (AIS) in Jakarta. The refugee children were provided with the opportunity to perform 
on stage at AIS and the cultural performance was highly appreciated by the AIS students, teachers and parents. The Australians gave their camera to refugees to film and take photos of their daily life, which refugees did enthusiastically and effectively. There are now many short films and hundreds of photographs of refugee children and their school.

The refugees started a Facebook page and other online sites for the CRLC, and shared their activities in and outside the school. Soon it started to attract attention from Australians, many frustrated by their government's OSB policy. They began to visit the school and donated books and stationery. In a few months, CRLC had a small library with more than 1,000 books. The students take these books on a daily basis and study and share them with their friends at school. Dozens of Australians from different backgrounds have so far visited CRLC which include academics, researchers, students, teachers, journalists, filmmakers and ordinary citizens. The New South Wales Teachers' Federation with the collaboration of Australian Teachers' Union sent two teachers from Australia to train CRLC teachers, as they were inspired by the work CRLC was doing for refugee children.

The Indonesian woman referred to above also played an important role because she was guiding and mentoring teachers about Indonesian customs and law. She helped to wake up the sleeping leaders within the refugee community by organising a living values workshop and retreat and encouraged them to lead in challenging situations. She identified leaders and enhanced their capabilities by attending the meetings and discussions.

The CRLC succeeded because refugees worked hard to establish it. It took a year of meetings, discussion and planning before inauguration. It is an example of the resourcefulness of refugees and proves they are capable and motivated. They not only established the CRLC but also a community which other refugees replicated. It was a pioneering step for all the refugees in Indonesia. The school and education for refugee children was the sacred cause, which removed all differences, overcame initial mistrust and brought them close to each other to help in running the school. 
Refugee women proved to be brave and bold to take risks in difficult situations. They gave women a new hope in a challenging time. They eventually became an integral part of the community with the massive contribution of educating the children.

The CRLC uses social media in a very effective way in order to establish a good network of friends and followers outside Indonesia, particularly in Australia ${ }^{15}$. The Facebook page was a chance for Australians to see what refugees can achieve if they are given opportunities. Online, Australians and refugees came face-to-face, perhaps for the first time. It is a window for both sides to develop better understanding and friendship. Australians have had a massive share in CRLC's achievements over the past two years. They have donated money, books, toys, stationery, provided teacher trainers, office equipment, carpets and tables for the school. The success story of CRLC is also a success story of Australian people and their love for refugees. It proved that they understand the situation from their own perspective in a realistic way, rather than relying on mainstream media outlets.

The importance of the CRLC was observed by Australian PhD student, Carly Copolov, on a recent visit to the school. She noted the dedication of the volunteer refugee teaching staff and observed the joy of the children: 'I had never seen children so excited to learn and the amount of respect they had for their teachers was impressive' (Copolov 2016).

\section{Concluding remarks}

Despite the hardships caused by their limbo status in Indonesia and the increasingly long waiting period for resettlement, refugee communities have been able to find opportunities in the uncertainty of their situation. While refugees have restricted rights in Indonesia and do not have a pathway for permanent residency there, they are nonetheless able to build relationships and mechanisms through which they can meet some critically important needs. For Bauman (2004), refugees are outcasts not knowing if their situation is temporary or permanent.

'Even if they are stationary for a time, they are on a journey that is never completed since its destination (arrival or return) remains forever unclear,

\footnotetext{
${ }^{15}$ CRLC has a Facebook page at https://www.facebook.com/cisaruarefugeelearningcentre/ and a website at http://cisarualearning.com/\#intro
} 
while a place they call 'final' remains forever inaccessible. They are never to be free from the growing sense of the transience, indefiniteness and provisional nature of any settlement' (Bauman 2004, p. 76).

While these sentiments cannot be denied, there exists an alternative story narrated by asylum seekers and refugees. As Ali noted above, skill sharing and solving of problems collectively had benefits for displaced communities residing in Cisarua. Here they were motivated to overcome hardship by working together to find their own unique solutions to the despair confronting them.

Arguably, there are difficulties of participation in constrained environments (Clarke 2010, p. 120). Refugees in Indonesia face constraints politically, economically, socially and from their status as outsiders with liminal legal status. Yet, inspiringly, the establishment of the Cisarua Refugee Learning Centre demonstrates how a community-based approach can harness human agency and spirit to overcome structural limitations and build strong community connections, both within like communities and across linguistic, cultural and national divides.

\section{References}

ABC News 2013, 'Immigration Minister Scott Morrison defends use of term 'illegal arrivals', plays down PNG police incident' (21 October), http://www.abc.net.au/news/2013-1021/immigration-minister-scott-morrison-defends-use-of-illegals-term/5035552 Accessed 14 February 2016

ABC News 2014a, 'Indonesia to raise Australian asylum seeker policy with United States', (14 February), http://www.abc.net.au/news/2014-02-14/australias-ambassador-injakarta-summoned-by-indonesian-governm/5261466 Accessed 14 February 2016

ABC News 2014b, 'Asylum seekers registered with UNHCR in Indonesia after June no longer eligible for resettlement in Australia, Scott Morrison says', (18 November), http://www.abc.net.au/news/2014-11-18/resettlement-path-for-asylum-seekers-inindonesia-cut-off/5900962 Accessed 18 February 2016

Agence France 2012, 'UN condemns Indonesia's increasing violence against Shiites' (13 November), http://asia-pacificsolidarity.net/southeastasia/indonesia/netnews/2012/ind42v16.htm\#Government\%20dis misses\%20'incidental'\%20religious\%20violence Accessed 21 February 2016.

Al Jazeera 2015, 'Indonesia "foils attack plot on Shia and Christmas"', Al Jazeera, (20 December), http://www.aljazeera.com/news/2015/12/indonesia-foils-attack-plot-shiaschristmas-151220113256410.html Accessed 21 February 2016.

Ahmed, K. 2014, 'Hunting the Hazara', Newsweek (11 March) http://newsweekpakistan.com/hunting-the-hazara/ Accessed 20 February 2016.

Agier, M. 2008, On the Margins of The World: The refugee experience today, Polity Press, Cambridge. 
Australia. Department of Immigration and Border Protection (DIBP), no date, Operation Sovereign Borders, Australian Government, Canberra. www.border.gov.au Accessed 12 February 2016.

Australian Customs and Border Protection Service and Australian Defence Forces (ACBPS and ADF) 2014, Joint Review of Positioning of Vessels Engaged in Operation Sovereign Borders, Commonwealth of Australia, Canberra. www.aph.gov.au/Parliamentary_Business/Committees/Senate/Foreign_Affairs_Defenc e_and_Trade/Breach_of_Indonesian_Territorial_Waters/Report/ /media/Committees/S enate/committee/fadt_ctte/Indonesia/report/e05.pdf. Accessed 16 April 2016.

Bachtiar, M. 2013, 'The growing influence of FPI and its impact on Indonesia', Jakarta Globe, (30 October), http://jakartaglobe.beritasatu.com/archive/the-growing-influenceof-fpi-and-its-impact-on-indonesia/ Accessed 22 February 2016.

Bauman, Z. 2004, Wasted Lives: Modernity and its Outcasts, Polity Press, Cambridge. Beyond Foreignness no date, 'Fortress Australia: Asylum Seeker and Migrant Death Statistics’ Beyond Foreignness. http://beyondforeignness.org/fortress-australia-asylumseeker-and-migrant-death-and-detention-statistics Accessed 21 February 2016.

Briskman, L. and Fiske, L. 2016, 'Creating criminals: Australia's response to asylum seekers and refugees' in Furman, R., Lamphear, G. and Epps, D. (eds.), The Immigrant Other: Lived Experiences in a Transnational World. Columbia University Press, New York, pp. 225-239.

Central Intelligence Agency (CIA), 2015, World Fact Book. Indonesia. Accessed 17 April 2016, https://www.cia.gov/library/publications/the-world-factbook/geos/id.html

Clarke, M. 2010, 'Re-imagining capacity building when participation is constrained: Illegal Burmese migrants in Thailand’ in Kenny, S. and Clarke, M. (eds.), Challenging Capacity Building: Comparative Perspectives, Palgrave Macmillan, Basingstoke, pp. 112-132.doi: http://dx.doi.org/10.1057/9780230298057_6

Copolov, C. 2016, 'This refugee life - opinion', Impact, 11 February, Accessed 11 February http://amesnews.com.au/latest-articles/refugee-life-opinion/

Ellis C., Adams T. E. and Bochner A, 2011, 'Auto ethnography: An overview', Forum Qualitative Social Research, vol. 12, no.1, http://www.qualitativeresearch.net/index.php/fqs/article/view/1589/3096 Accessed 11 May 2016.

Fleay, C., Cokley, J., Dodd, A., Briskman, L. and Schwarz, L. 2016, 'Missing the Boat: Australia and asylum seeker deterrence messaging', International Migration, doi: http://dx.doi.org/10.1111/imig.12241

Gifford, S. 2015, 'Where does the magic number for Australia's refugee intake come from?' The Conversation, 11 September. http://theconversation.com/where-does-the-magicnumber-for-australias-refugee-intake-come-from-47204 Accessed 14 February 2016

Global Detention Project, 2016, Indonesia Immigration Detention Profile, http://www.globaldetentionproject.org/countries/asia-pacific/indonesia Accessed 17 April 2016

Handayani, I.P. 2012, 'Beyond statistics of poverty.' Jakarta Post (13 February) http://www.thejakartapost.com/news/2012/02/13/beyond-statistics-poverty.html Accessed 20 February 2016

Hazara Asylum Seekers 2015, Hazara Asylum Seekers Facebook Page, (posted 11 February 2015) https://www.facebook.com/HazaraAsylumSeekers/posts/914192308615118?fref=nf Accessed 20 February 2016.

Human Rights Watch (HRW) 1998, 'The massacre in Mazar-I-Sharif' Human Rights Watch Reports, 10(7). Human Rights Watch, New York. https://www.hrw.org/legacy/reports98/afghan/ Accessed 20 February 2016. 
Human Rights Watch (HRW) 2013, Barely Surviving. Detention, Abuse, and Neglect of Migrant Children in Indonesia. Human Rights Watch, New York. https://www.hrw.org/report/2013/06/23/barely-surviving/detention-abuse-and-neglectmigrant-children-indonesia Accessed 12 February 2016.

Missbach, A. 2015, Troubled Transit: Asylum Seekers Stuck in Indonesia, Yusof Ishak Institute, Singapore.

Missbach, A. and Sinanu, F. 2013, 'Life and death in immigration detention', Inside Indonesia, 113 (July-September) http://www.insideindonesia.org/life-and-death-inimmigration-detention Accessed 21 February 2016.

Nethery, A., Rafferty-Brown, B. and Taylor, S. 2014, ““At the discretion of management”: Immigration detention in Indonesia', in Nethery, A. and Silverman, S. (eds.), Immigration Detention: The migration of a policy and its human impact, Routledge, Abingdon, pp. 114-124.

Organisation for Economic Co-operation and Development (OECD) 2015, OECD Economic Surveys. Indonesia 2015. OECD Publishing, Paris.

Sampson, R.C., Gifford, S. M., Taylor, S. 2016, 'The myth of transit: The making of a life by asylum seekers and refugees in Indonesia', Journal of Ethnic and Migration Studies, vol. 42, no. 7, pp. 1135-1152. doi: http://dx.doi.org/10.1080/1369183X.2015.1130611

UNHCR 2016, Indonesia Fact Sheet. February. UNHCR, Jakarta. http://www.unhcr.org/50001bda9.pdf Accessed 11 May 2016.

UNHCR 2015b, Global Appeal 2016 - 2017. UNHCR, Geneva. http://www.unhcr.org/pages/49c3646c4b8.html Accessed 2 February 2016.

UNHCR 2012, 2012-2016 Education Strategy. http://www.unhcr.org/cgibin/texis/vtx/home/opendocPDFViewer.html?docid=4af7e71d9\&query=education Accessed 14 February 2016

UNICEF 2012, Basic education and gender equality, http://www.unicef.org/education/index_44870.html Accessed 14 February 2016

United States Commission on International Religious Freedom (USCIRF), 2013, Indonesia: A New Culture of Intolerance Threatens Religious Minorities, Accessed 17 April 2016. http://www.uscirf.gov/sites/default/files/resources/Indonesia\%20Factsheet\%20\%200C TOBER\%20\%202013\%20finalrev.pdf

von der Mehden, F. 2014, 'Saudi religious influence in Indonesia' Middle East Institute, (1 December) http://www.mei.edu/content/map/saudi-religious-influence-indonesia Accessed 21 February 2016. 